\title{
KATHERINE MANSFIELD'S ANIMAL AESTHETICS
}

Derek Ryan

In a letter to John Middleton Murry, sent on 25 November 1919 from Ospedaletti, Katherine Mansfield responds critically to Sydney Waterlow's lead article in that week's Athenaeum, which marked the centenary of George Eliot's birth:

I dont [sic] think S. W. [Sydney Waterlow] brought it off with George Eliot. He never gets under way. The cartwheels want oiling. I think, too, he is ungenerous. She was a deal more than that. Her English, warm, ruddy quality is hardly mentioned. . . But think of some of her pictures of country life —-the breadth—the sense of sun lying on long barns—great warm kitchens at twilight when the men came home from the fields-the feeling of beasts horses and cows-the peculiar passion she has for horses (when Maggie Tullivers [sic] lover walks with her up \& down the lane \& asks her to marry, he leads his great red horse and the beast is foaming - it has been hard ridden and there are dark streaks of sweat on its flanks-the beast is the man one feels SHE feels in some queer inarticulate way)—Oh, I think he ought really to have been more generous. 
In his piece, Waterlow doesn't ignore Eliot's "pictures of country life" entirely. But where he sees Eliot as an "admirable pastoral writer" in whose books "the hierarchy of beast and labourer, farmer, parson and squire in their setting of quietly undulating elmbordered field" are "preserved . . . motionless in a kind of golden haze" (1217), Mansfield's retort suggests a livelier reading of Eliot's human and nonhuman figures as unsettling such hierarchies. Her phrase "the beast is the man one feels SHE feels" expresses a double movement whereby human and nonhuman figures have some sort of affinity with each other just as the reader is invited into the writer's animal affections. Given that Waterlow reverts to essentialist language to point out Eliot's inability to make a success of her "natural bent" of the "exquisite feminine vein" "towards reproduction rather than towards inventive creation" (1218)—she makes the mistake, we are told, of exploring "the world of intellectual abstractions which is properly preserved for males"it is unsurprising that in rebuking him Mansfield feels that "I must stand up for my SEX" ("To J. M. Murry," 25 Nov. 1919, 118). There is more than a hint that this comment is also directed at Murry, who was then editor of the Athenaeum, for not choosing her to write the article on Eliot despite the fact Mansfield had told him she would "love to do something" (“To J. M. Murry," 23 Oct. 1919, 46).

The passage Mansfield refers to in her letter to Murry occurs toward the end of Eliot's 1860 novel The Mill on the Floss. When Stephen Guest, arriving in search of Maggie Tulliver, appears as "a gentleman on a tall bay horse; and the flanks and neck of the horse were streaked black with fast riding" (412), we find man and beast aligned in their sweaty urgency. Feeling "horrible" at the sight of them, Maggie's bodily response nonetheless seems to reverberate directly from the horse: she "felt a beating at head 
and heart." As she attempts to walk away after rejecting Stephen's marriage proposal, her indecision and frustrated desire appear to be sensed by the horse, which "began to make such spirited remonstrances against this frequent change of direction" (414). She is explicitly compared to an animal, both tame and wild, in a simile a few paragraphs later that encapsulates her emotional tumult: "Her lips and eyelids quivered; she opened her eyes full on his for an instant, like a lovely wild animal timid and struggling under caresses" (415, emphasis added). We cannot know if Mansfield would have expanded on the intersection of gender and animality had she written more on Eliot, but she clearly recognized it as an important feature of The Mill on the Floss. The novel frequently compares its human characters to the domesticated and farmyard animals surrounding them. ${ }^{1}$ It also shows Maggie's childhood fascination for "countries full of those creatures" such as "elephants, and kangaroos, and the civet cat, and the sun-fish" (29) and for "lion countries—I mean in Africa" (33). The attempt to understand humans in relation to animals signals that this text (published one year after On the Origin of Species) is conscious of evolutionary theory, of both the closeness to and "that difference between the man and the monkey" $(264) .{ }^{2}$ There is sometimes even a tentative portrayal of animals' inner lives in Eliot's novel, which often centers on the horses and their responses to being controlled by unsympathetic men. It is in these scenes, in which we witness encounters between humans and actual animal figures, that Eliot foregrounds a distinctly gendered power dynamic. Eliot details how the emergence of masculine subjectivity through childhood is linked to "that desire for mastery over the inferior animals, wild and domestic" (87); in adulthood this masculine subjectivity is often signaled, as in Mr. Tulliver's behavior, by the spurring and whipping 
of a horse (330). ${ }^{3}$ Rather than simply reproducing bucolic scenes from memory, as Waterlow suggests, Eliot is partaking in "inventive creation" in her deployment of animal figures to variously interact with, enhance, complicate, or undermine the novel's focus on human relationships.

Mansfield's all-too-brief reading of Eliot is, as Gerri Kimber and Angela Smith remark, a "tantalising insight into what might have been" had she been given the opportunity to review "the writers she most valued and understood" ("Reviews" 426). But more specifically (and intriguingly), it offers insight into Mansfield's interest in the way that literary texts explore interspecies relations and the boundaries between humanity and animality. When reflecting on her own writing in a letter to Dorothy Brett, when she was in the midst of rewriting "The Aloe" as "Prelude," Mansfield explains:

When I write about ducks I swear that I am a white duck with a round eye, floating in a pond fringed with yellow blobs and taking an occasional dart at the other duck with the round eye, which floats upside down beneath me. In fact this whole process of becoming the duck ... is so thrilling that I can hardly breathe, only to think about it. For although that is as far as most people can get, it is really only the "prelude." There follows the moment when you are more duck, more apple or more Natasha than any of these objects could ever possibly be, and so you create them anew. (“To Dorothy Brett," 11 Oct. 1917, 330)

In addition to offering "a clue" as to how Mansfield arrived at the "enigmatic title" of her 1918 story (Jones 298), this passage focuses on anatine animality in order to articulate a theory of aesthetics that exceeds mere representation. ${ }^{4}$ This idea of "becoming" has 
been taken up by critics who examine the role of animals in Mansfield's work. Peter Matthews, for example, argues that Mansfield's 1922 story "At the Bay" offers a "transformative philosophy of becoming" (53), one that emphasizes "a series of fragments, disjunctions, and alliances" (50). "At the Bay," in his reading, "overturns the anthropocentric view of the world by foregrounding, from an inhumanly distant perspective, the landscape and the actions of the animals" (52). Curiously, however, Matthews doesn't mention Mansfield's most explicit affirmation of becoming through writing that we see in the above letter. ${ }^{5}$ Melinda Harvey uses the "process of becoming the duck" to locate Mansfield among such contemporaries as Franz Kafka, D. H. Lawrence, Ernest Hemingway, and Marianne Moore, all of whom likewise "refuse to participate in making the animal disappear" (203). More than that, Harvey claims that Mansfield's writing can be situated in a tradition of often unnoticed literary efforts in "the critique of anthropocentrism and the pursuit of an animal-centred discourse" (202); instead of viewing them as abstract, figurative "emblems" (206), Harvey reads animals as "co-actors" in the worlds Mansfield's stories create. To different degrees, then, these readings agree that Mansfield foregrounds animals in her work in order to reject anthropocentrism and the oppositional categorization of human and nonhuman life.

Mansfield at times directly reflects on how what a "pity" it is "that human beings live so remote from all animals" ("To S. S. Koteliansky," 7 Apr. 1919, 309), a comment that can be understood as part of her wider concern with the entanglement of humans and the environment: "why is there this division between humanity \& the lovely external world —With all this beauty why cant [sic] we all come forth radiant?" ("To Ottoline Morrell," May 1919, 317). But to claim that she held this as a consistent view, or that her 
writing overcomes the distinction between human and animal, is to overstate the significance of these remarks and to overlook the complexity of her depiction of animality. In addition to her reading of Eliot, Mansfield was attentive not only to her contemporaries' depictions of animals but also to distinctions between their aesthetic projects and hers. Her reading of D. H. Lawrence, for example, suggests she disliked the idea of her writing being grouped with his. In her October 1917 letter to Brett she distances her approach to literary aesthetics from his, mockingly noting that what she called "becoming" he would call "consummation with the duck" (330). The sentiment echoes her complaint in a previous letter to Beatrice Campbell that Lawrence is too "phallic" (4 May 1916, 261). This chimes with her remarks that to read Lawrence is to feel that he "had possessed an animal \& had fallen under a curse" ("The Lost Girl" 708); according to Mansfield, Lawrence's particular form of animality is too base in that he "he denies his humanity" (706) and "he denies human life," including the "powers of the imagination" and the very ability to "feel," "speak," and think. This critique implies that Mansfield sees her own version of becoming animal as maintaining these distinctly human qualities, even if that means falling back on the very capacities that have been used to divide human and animal in Western thought. Manfield elsewhere suggests it is a more embodied humanity that is missing in modernist animal writing. ${ }^{6}$ Responding to Virginia Woolf's 1919 short story “Kew Gardens," Mansfield turns Woolf into a figurative animal to emphasize this point: Woolf writes from a "bird's eye" perspective (333); "she hovers over, dips, skims, makes exquisite flights—sees the lovely reflections in water that a bird must see—but not humanly" (“To Ottoline Morrell," 27 June 1919, 333-34). ${ }^{7}$ Whatever objections we might raise to Mansfield's characterizations of Lawrence and 
Woolf, her remarks once again illustrate that she was attuned to the nuances of animal aesthetics.

This essay argues that Mansfield's attentiveness to how animals feature in literary creation is central to the development of her own modernist practice and the emergence of nonhuman subjects in her texts. But instead of rushing to claim her as part of an anti-anthropocentric group of contemporaneous writers, it suggests that her modernist animal aesthetics emerge tentatively and, as such, require careful consideration of her multiple and shifting attempts to write animality. Rather than altogether disposing of hierarchical oppositions between human and animal, a close reading of her texts shows how she often probes and plays on species boundaries, occasionally reinscribes and sometimes redraws them, and yet rarely moves entirely beyond them. The first part of this essay focuses on the presence of animal figures and worlds in Mansfield's "Prelude," first published by Virginia and Leonard Woolf's Hogarth Press, and "At the Bay," which the author called her "continuation of 'Prelude"' ("To Dorothy Brett," 12 Sept. 1921, 278). In both texts elements of Eliot's The Mill on the Floss are evident, whether in the stories' gendered power dynamics or in their responses to Darwinism. The significance of Mansfield's writing of animality in these two stories is illuminated by their intertextual relationship and by the ways they allude to texts by writers who influenced her, such as Henrik Ibsen and Anton Chekhov. The second part of the essay considers Mansfield's further engagement with and observations of animals in terms of both her creative output and her personal experiences over the final years of her life. Read from this perspective, Mansfield's writing rewards what we might describe, following Susan McHugh's account of 
"narrative ethology" (5), as an ethological reading practice, one that necessitates close attention to how animals behave in the distinct environments of a particular author's sentences and stories. ${ }^{8}$

\section{Classification and Transformation: "Prelude" and "At the Bay"}

Animals in Mansfield's early stories fulfill quite traditional literary functions. The very earliest of these, written in her mid-teens, alternate between situating animals (such as the New Zealand tui and morepork owl) as background figures that add local color to depictions of her hometown of Karori and straightforward, sentimental anthropomorphism: for instance, in her description of the "little husband and wife sparrow who had evidently gone out house-hunting" in "The Pine Trees, The Sparrows, and You and I" (10). ${ }^{9}$ Women are associated with animality in stories such as "Die Einsame (The Lonely One)," in which the main character is a "creature of the forest" (20). Birds reappear as obvious symbols of freedom (or the lack thereof) in "Juliet," whose protagonist lists "Nature" (42) as the first of her "four passions" (39). Even when animals begin to feature more prominently, Mansfield's figurations remain much the same. In "Something Childish But Very Natural," written in 1914, the Samuel Taylor Coleridge poem from which the title is taken illustrates why some critics view the Romantics' use of animals as resting on an identification with nature so anthropocentric that "the bird is hardly there" (Perkins 142): "Had I but two little wings / And were a little bird / To you l'd fly" (373-74). ${ }^{10}$ The poem's function in Mansfield's story suggests complicity rather than critique: Henry is "charmed" by it and it comes to symbolize his love for Edna (374). Mansfield's identification with birds appears, too, in such poems as "When I Was a Bird," "Winter Bird," and "The Wounded Bird." It was in later years that 
Mansfield would become more self-conscious about her literary animals, worrying on completion of "Mr. and Mrs. Dove" in 1921 that the story was too heavy-handedly symbolic: "I have a sneaking notion that I have, at the end, used the doves unwarrantably. ... I used them to round off something, didn't I? Is that quite my game? No, it's not. It's not quite the truth I am after" (Newberry Notebook 7278).

When it comes to animals, what is the truth Mansfield was after? To explore this question we must turn to the two stories in which her depiction of animals and their relationship with language is at its most complex: "Prelude" and "At the Bay." Given their setting in rural New Zealand, it is hardly surprising that they contain the most varied and abundant interest in animals found across Mansfield's work. Moreover, the fact that they are closely related in terms of setting, character, theme, and form-even though they were written four years apart—makes them useful for tracing continuities and developments in her depiction of nonhuman life. Read together, they show us the subtle shifts in Mansfield's animal aesthetics by exhibiting two features that align with the competing impulses of becoming and distinction: first, the kinds of figurative transformations that human and animal figures undergo, alongside material encounters of certain characters with nonhuman alterity; and second, the classification of humans and animals into distinct groupings, characterized by the tendency to name and capture. Both "Prelude" and "At the Bay" are marked in different ways and to varying extents by the relationship between these two processes.

In "Prelude," characters appear to be on the verge of transformations from human to animal. The voices of the children are heard at first as "chirrups," a sound typically associated with birds or crickets (57); Alice is described as "baa-baaing through 
the garden" (67); and on more than one occasion Kezia "gave a little squeak" (65).

There are apparently corporeal transformations too. Just after we read that "everything familiar was left behind" (60), Lottie's bodily movements become akin to a lapdog's: her "head wagged; she dropped, she slipped half into Kezia's lap and lay there." Later the birdlike Kezia "seemed to come flying through the air" as she approaches Lottie (61), who herself is "like a bird fallen out of the nest" (61). Stanley is found "squatting like a frog" (66), Linda suggests he looks "like a big fat turkey" (67), and Rags has "shoulder blades [that] stuck out like two little wings" (78). The human characters are animalized through this use of figurative language, yet the narrative skims over any concern with the animals on which these similes depend. What is enhanced is less our knowledge of the characters' animality than it is our understanding of their bodies and behaviors.

While these animals are evoked in only a vague, generalized sense as they play their roles in figurative transformations of the human, elsewhere Mansfield's narrative attends to the classification of distinct groups and species. For example, the use of the broad term "bird" can be contrasted with the beginning of section 5 , which details seven different types: "Big cheeky birds, starlings and mynahs, whistled on the lawns, the little birds, the goldfinches and linnets and fantails flicked from bough to bough. A lovely kingfisher perched on the paddock fence preening his rich beauty, and a tui sang his three notes and laughed and sang them again" (66). This passage is certainly "bursting with animal sights and sounds" (Harvey 206), but it is immediately followed by Linda Burnell's dream, in which she sees a (once-again generalized) "little bird" ("Prelude" 66) while out walking with her father, only for the bird to "swell" and transform into "a baby with a big naked head and a gaping bird mouth" after she had "stroked it." The content 
of this dream, with its highly gendered association of female sexuality with childbirth, exemplifies how in human minds animals become more homogenized—and humanized—as they become symbolic. ${ }^{11}$ Later, Alice is reading "the Dream Book" (83), which details the symbolic meaning of black-beetles ("Signifies death of one you hold near or dear") and spiders ("Signifies large sum of money in near future"). These descriptions ironically expose the irrationality of the way we often integrate animalstraditionally viewed as creatures lacking rationality_into our minds. Mansfield draws attention to a central tension involved in writing about animals, wherein the use of animals to transform elements of a human character's corporeality or psychology by necessity conflicts with the ability to represent the specificity of the animals themselves.

The asymmetrical relationship between humans and animals is not only present on a symbolic level in "Prelude." It also appears in the treatment of the mongrel dog Snooker, who on the one hand evades classification in terms of breed but on the other is clearly ranked below the Trout boys, Pip and Rags, who tie a "funny handkerchief" (80) around Snooker's head "to train his ears to grow more close to his head" so that he will be transformed into one of the "fighting dogs." The narrator makes clear that this is far from mere fun and games by turning the focus back to the dog, which "tried to sneak away" and "made one feeble effort with his paw to get the handkerchief off, but finding he could not, trailed after the children, shivering with misery." As in Eliot's The Mill on the Floss, the emergence of masculine subjectivity is linked here to "mastery over the inferior animals" (Eliot 87). Tellingly, the scene prefigures a much more brutal one, as if to show how the boys are primed to follow in the footsteps of the handyman Pat. He begins section 9 of the story "swinging along" with a "tomahawk" in his hand (Mansfield, 
"Prelude" 80), preparing to show the children "how the kings of Ireland chop the head off a duck," with the sense of his going into battle reinforced by his description of the ducks as "a little Irish navy" (81) including an "admiral" with "a grand little flagstaff on his tail."12 At the same time that Mansfield exposes how anatine figures are overlaid with symbolic significance for the adult Pat, the militaristic language heightens the atmosphere of impending violence.

By contrast, the children's first reaction is to classify "a real duck's head . . . from the paddock" (80), and over the next few paragraphs the narrator provides a detailed description of the territory where the "the big white ducks had made themselves at home, swimming and guzzling along the weedy banks" (81) while "preening their dazzling breasts." The narrative focus is firmly on the ducks' appearance, behavior, and environment, but Pat soon encroaches on their territory. He imitates duck sounds to lure them to their demise, his animalized voice actually upholding his sense of human sovereignty:

'Lid. Lid - lid - lid - lid -' he called. 'Qua. Qua - qua - qua - qua -' answered the ducks, making for land, and flapping and scrambling up the bank they streamed after him in a long waddling line. He coaxed them, pretending to throw the grain, shaking it in his hands and calling to them until they swept round him in a white ring. (81)

After Pat "stooped" and "seized" two ducks (81), we are told in striking detail how one of them is killed: "Pat grabbed the duck by the legs, laid it flat across the stump, and almost at the same moment down came the little tomahawk and the duck's head flew off the stump. Up the blood spurted over the white feathers and over his hand." Human and 
animal may both be bloodied here, but only one is mutilated. Indeed, Pat and the children revel in the spectacle to the point that "[e]ven Lottie, frightened little Lottie, began to laugh and pointed at the duck and shrieked" (82) and "Pip forgot all about his duck. He simply threw it away from him and shouted, 'I saw it. I saw it."' Where Mansfield's narrative briefly deploys anthropomorphism to describe Snooker's "misery," here there is no sign of the duck's experience as it is reduced to an object to be gazed at. Pat calls for everyone to "Watch it!" as the beheaded duck "began to waddle—with only a long spurt of blood where the head had been," before Isobel continues the Cartesian tradition of viewing the animal as machine with the simile "[i]t's like a funny little railway engine." The reinsertion of figurative language, combined with the animalas-machine analogy, works to remove us further from any notion of "real" ducks (80). Kezia is the character most traumatized by the duck's violent death. "Put head back!" she screams repeatedly (82), to the point that her voice becomes "like a loud strange hiccup." That it is one of the girls who sympathizes with the duck points once again to the asymmetrical way that gender intersects with cruelty toward animals. Kezia's subsequent surprise at her discovery that Pat, a man, "wore little round gold ear-rings" undercuts the virile masculinity that fuels the violence. Kezia, in Smith's words, "notice[s] contradictions in what seems a definitely gendered identity" (Katherine Mansfield and Virginia Woolf 95). Nonetheless, masculine dominance is reinscribed in section 11 when readers witness the pleasure Stanley Burnell derives from "carving" the duck with "precision" (85) even as he compares Alice to the dead animal that lays in "basted resignation" (84) on the table:

It was hard to say which of the two, Alice or the duck, looked the 
better basted; they were both such a rich colour and they both had the same air of gloss and strain. ...

Burnell ran his eye along the edge of the carving knife. He prided himself very much upon his carving, upon making a first-class job of it. He hated seeing a woman carve; they were always too slow and they never seemed to care what the meat looked like afterwards. Now he did; he took a real pride in cutting delicate shaves of cold beef, little wads of mutton, just the right thickness, and in dividing a chicken or a duck with nice precision. . . . (84-85)

Here Burnell isn't just dividing the duck; he is also carving up a hierarchy of man over and above both women and animals. He may derive a certain pride and delicacy in the activity, but it is one that reinforces a superior masculine status. As such, the scene can be read as exemplifying Carol Adams's claim that there is a "heightened sensitivity by twentieth-century women writers to violence against animals" (186), which serves as part of her wider argument that in the modern world women are increasingly animalized and animals feminized—a dual process that upholds patriarchal cultures.

Kezia's response, coupled with the gender dynamics of this section's treatment of the duck, evokes a significant anatine figure found in a play by one of the writers Mansfield most admired: Henrik Ibsen's 1884 The Wild Duck. In her empathy for the duck Kezia shares something with Hedvig, the teenage daughter in Ibsen's play, who feels a deep affection for the "real wild bird" the Ekdal family keep in their loft (Ibsen $160)$, the emphasis on its realness echoing the initial concern of the children in Mansfield's story. Crucially, Hedvig's care for the duck is repeatedly juxtaposed with the 
threat of violence from men who, as her mother Gina puts it, constantly have to "deviate themselves" with hunting (163). When her father Hjalmar directly threatens "[t]hat damned wild duck" (179)_-"'d like to wring its neck," he says—Hedvig's response is, like Kezia's, to scream. For Hjalmar the duck becomes a symbol of deceit-it was initially shot and captured by Haakon Werle, who Hjalmar learns had an affair with his wife-that must be sacrificed to meet the "demands of the ideal" and cleanse "his own soul," whereas for Hedvig it remains a "poor little wild duck." While Hedvig grows convinced by her father's threats and by Gregers's preaching that the duck should be "sacrificed . . for his sake" (199), the fact that Ibsen closes with the tragic suicide of Hedvig rather than the death of the duck, which presumably she could not bring herself to kill, reinforces the gendered nature of violence in the play. In different ways, then, Ibsen's The Wild Duck and Mansfield's "Prelude" expose both symbolic and material violence toward women and animals.

Described by Mansfield as her "seaweedy story" ("To Dorothy Brett," 15 Oct. $1921,295)$ that she hoped would smell "a little bit fishy" ("To Dorothy Brett," 4 Aug. 1921, 261), "At the Bay" not only displays continuities with "Prelude" in terms of setting, character, and theme but also in its use of animal figures. Most obviously, similar animalistic similes are used to describe the characters. The appropriately named Jonathan Trout moves his hands "like fins" ("At the Bay" 345), little girls "ran into the paddock like chickens let out of a coop" (348), two little boys on the beach "twinkled like spiders" (350), Beryl swims "like a rat" (353), Stanley has "the look of a trapped beast" (355), and Alice jumps "like a cat" (361). Structurally there are echoes too, with section 9 of "At the Bay" offering the most extensive exploration of animality, just as it does in 
"Prelude." As the section opens, tensions between transformation and classification appear to have been resolved in that the children have imaginatively metamorphosed and each become identical to a specific kind of animal. The narrator informs us in a matter-of-fact way that "[a] strange company assembled in the Burnells' washhouse" (361): "[r]ound the table there sat a bull, a rooster, a donkey that kept forgetting it was a donkey, a sheep and a bee." However, the species of animal each child has becomeand even the category of "animal" itself-is soon unsettled as the children squabble and joke over definitions:

"You can't be a bee, Kezia. A bee's not an animal. It's a ninseck" "Oh, but I do want to be a bee frightfully," wailed Kezia. . . . A tiny bee, all yellow-furry, with striped legs. She drew her legs up under her and leaned over the table. She felt she was a bee.

"A ninseck must be an animal," she said stoutly. "It makes noise. It's not like a fish."

"I'm a bull, I'm a bull!" cried Pip. And he gave such a tremendous bellow—how did he make that noise? — that Lottie looked quite alarmed. "I'll be a sheep," said little Rags. "A whole lot of sheep went past this morning."

"How do you know?"

"Dad heard them. Baa!" He sounded like the little lamb that trots behind and seems to wait to be carried.

"Cock-a-doodle-do!" shrilled Isabel. With her red cheeks and bright eyes she looked like a rooster. 
"What'll I be?" Lottie asked everybody, and she sat there smiling, waiting for them to decide for her. It had to be an easy one.

"Be a donkey, Lottie." It was Kezia’s suggestion. "Hee-haw! You can't forget that." (361-62)

On first reading, the playful manner in which the children attempt to classify what counts as "animal" comically exposes the superficiality of their method. Though there is a kind of transformation from human to animal, the ease with which they decide to switch roles makes clear that this is merely imitation: 'I've forgotten what I am,' said the donkey woefully" (363). The response: "Well, change! Be a dog instead! Bow-wow!"

But this passage hints at a more important aspect to the role animality plays in "At the Bay." The tension between classification and transformation can be read here in zoological terms: that is, between the taxonomic study of animals, which deals in lifeless specimens, and the theory of evolution, which brings to life the biological and ethological history of species. As they grasp to comprehend the animal kingdom and their place in it, the children — with their emphasis on looks and sounds—fall into what Darwin refers to as analogical classification, which focuses on "resemblances" based on "external appearance" (491). Indeed, the scene's focus on the children's trying out of various actions and behaviors in order to imitate certain animals reflects some of biologists' early attempts to understand evolutionary processes; most notably, it recalls Jean-Baptiste Lamarck's emphasis on "conscious endeavour" and "intelligent desire" as "agents of evolutionary change" (Beer 19). The fanciful nature of the children's transformations matters less than the sheer liveliness of their embodied, imaginative exchange of species identity, and can be contrasted with Mansfield's send-up of 
misunderstandings of Darwinian classification in early draft material for "At the Bay." Mansfield details "Miss P's" love for "serious books" like Darwin's (Notebook 42 164), only for her to struggle to remember which of his texts she has actually read:

Why I don't know when I've enjoyed a book as much as—as-dear me! How silly! Its on the tip of my tongue. Darwin's—one moment-its coming—Darwin's Decline \& Fall. No, no. That wasn't the one. That's not right now. Tchuh! Tchuh! You know how it is. I can see it quite plainly and yet ... l've got it! Darwin's Descent of Man! . . Was that the one, though? Do you know now l'm not certain? I feel it was and yet somehow its unfamiliar. This is most extraordinary. And yet I enjoyed it so much. There was a ship. Ah! That's brought it back. Of course. Of course! That was the one. Darwin's Voyage of the Bugle! (Notebook 42 164)

Over the course of a few sentences, Miss P manages to confuse Darwin with Edward Gibbon's eighteenth-century tome The History of the Decline and Fall of the Roman Empire, to mix up Darwin's own texts, and then finally — when she does pin down which book it was—she gets the name wrong (substituting "Bugle" for "Beagle"). When compared to the lively, inventive behavior of the children, this passage clearly satirizes intellectual pretentiousness and the desire to capture and contain knowledge. What Mansfield herself appears to share with Darwin is less his knowledge of the finer details of zoology and more his attempt to tell "a story of the world—a fiction ... which deliberately extends itself towards the boundaries of the literally unthinkable" and is therefore full of transformational potential (Beer 92). ${ }^{13}$

The imaginative effort to understand how animal behaviors relate to their 
environments is more pronounced in "At the Bay" than in "Prelude," as evidenced in the pastoral scene near the beginning of the former: "Round the corner of Crescent Bay, between the piled-up masses of broken rock, a flock of sheep came pattering. They were huddled together, a small, tossing, woolly mass, and their thin, stick-like legs trotted along quickly as if the cold and the quiet had frightened them" ("At the Bay" 343). Following the sheep is "an old sheep-dog, his soaking paws covered with sand," running "with his nose to the ground": "then in the rocky gateway the shepherd himself appeared." The narrative not only mimics the nature of herding, whereby the flock of sheep lead the way ahead of their "master," but gives these sheep a primary role in introducing the story's animal aesthetics. Here, the narrator focuses on the materiality of the sheep's bodies as well as their physical movements: "pattering," huddling, and trotting (343); and, on the following page, "pushing, nudging, hurrying" (344)..$^{14}$ In her concern for the sheep's physicality and movements, Mansfield departs from the famous ovine passages that she was rereading around the time that she was writing "At the Bay": the "Shepherd scene" in Shakespeare's The Winter's Tale ("To Ottoline Morrell," 24 July 1921, 253) and the "swollen sheep that looks up \& is not fed" in Milton's Lycidas (“To Dorothy Brett," 29 July 1921, 257). Through its detailed depiction of the primacy of the sheep, Mansfield's opening can also be productively contrasted with Chekhov's story "Happiness" (or "Fortune"), which she would have known through Constance Garnett's 1918 translation. Like "At the Bay," Chekhov's story begins with a "flock of sheep," but quickly turns its narrative focus to the "two Shepherds guarding it" and "a serious, reasonable man who knew his own value." In place of Mansfield's rich descriptions of their bodily activity, Chekhov's sheep are mostly "asleep" and those that 
aren't are merely "silhouettes of sheep." Where Mansfield creates a literary landscape populated by lively animals, Chekhov's focus remains centered on his human figures. Matthews rightly notes that the narrative order at the beginning of "At the Bay" establishes a "perspectival inversion" of human and animal (52), but in his designation of the sheepdog as the "chief actor" who "controls the movement of the group" Matthews risks replacing one hierarchical figure with another, albeit nonhuman, one. Even more significant is the shared agency of sheep and sheepdog in the way they enter the narrative. The narrator's description of herding not only focuses on the external appearances, behaviors, and environments of the nonhuman figures; it also speculates on the feelings and thoughts of the sheep and sheepdog by entering into a figurative realm. The sheep act "as if" they are "frightened" and the sheepdog runs "carelessly, as if thinking of something else"; tellingly, the shepherd is the one character in this scene whose inner experience the narrator doesn't delve into at all. Alongside the various uses of figurative language to embellish the features and feelings of human characters in both "Prelude" and "At the Bay," then, in the latter story Mansfield begins to speculate, albeit hesitatingly, as to how the animals themselves might relate, physically and emotionally, to each other and to their environments. This attempt to probe the inner worlds of animals is evident elsewhere in "At the Bay," most notably in Mansfield's portrayals of the dog Snooker and cat Florrie. At one point we read that Snooker "gave an occasional desperate-sounding puff, as much as to say he had decided to make an end of it and was only waiting for some kind cart to come along" (356-57); this suggests a range of emotions, including the dog's awareness of death. We also read that Florrie "looked content, as though she had been waiting for this 
moment all day" (367), implying an ability to comprehend the logic of delayed gratification. Mansfield even opts to give the cat the capacity for human speech when expressing disgust at the sheepdog: “Ugh! What a coarse, revolting creature!' said Florrie" (344). ${ }^{15}$

Whether signaled through figurative language or more extravagantly through direct speech, there is more anthropomorphism in these examples than can be found in "Prelude." This point can be illustrated through a direct comparison of references in both stories to a far-off dog. In "Prelude," the dog is immediately integrated into human symbolic associations and myth: "Far away a dog barked. 'I believe there is going to be a moon,' she [Linda] said" (76). In "At the Bay," narrative focus remains on the dog itself as we read that, disturbingly, "from far away they heard a dog barking; it was muffled as though the dog had its head in a sack" (364). These passages illustrate that Mansfield's increased use of anthropomorphic projection in the later story, in which human characteristics are attributed to nonhumans, is deployed in an effort to make these animals into characters in the foreground of the narrative rather than creatures lurking in the background. That is, Mansfield matches her figurative use of animals with the emphasis she places on the materiality of their bodies and surroundings. This provides a further point of contrast to Chekhov's "Happiness," in which the sleeping sheep later waken and are described as "thinking" and "pondering." Because such anthropomorphic projection isn't combined with the detailed narrative focus that we find in Mansfield, however, the presence of the sheep feels mainly symbolic of the vast mystery of the southern Russian steppe; in this sense, they remain "silhouettes." In refining her animal aesthetics in "At the Bay," then, Mansfield gradually intensifies her focus on nonhuman 
life. Whereas both "Prelude" and "At the Bay" often use figurative language to depict human qualities, it is in the latter that Mansfield more fully expands on animals' inner experiences and active engagement with their environments. In other words, Mansfield harnesses linguistic devices precisely to give her literary animals a life of their own.

\section{Watching and Writing; or, "Becoming Absorbed in Animals"}

Just as animals were staking their territory in her stories, Mansfield's own engagement with nonhuman lives and environments was increasingly evident in her letters. From Menton, France in September 1920 she writes to Murry of being captivated by the creatures thriving in the warm Mediterranean climate: "Already one listens for the grasshoppers' fiddle, one looks for the tiny frogs on the path—one watches the lizards" ("To J. M. Murry," 19 and 21 Sept. 1920, 44). By the following week her observations intensify:

The lizards here abound. There is one big fellow, a perfect miniature crocodile who lurks under the leaves that climb over a corner of the terrace. I watched him come forth today—very slithy—and eat an ant. You should have seen the little jaws-the flick of the tongue, the queer rippling pulse just below the shoulder. His eyes, too. He listened with them-and when he couldn't find another ant he stamped his front paw and then seeing that I was watching deliberately winked, and slithered away. ("To J. M. Murry," 27 Sept. 1920, 53)

Mansfield describes a world that the human remains outside of, observing but never intruding on a nonhuman environment "rippling" with the "pulse" of life. (In this sense, it 
is the opposite of Pat's treatment of the ducks in "Prelude.") Detailing an interspecies relationship between lizards and ants, Mansfield focuses on their varied corporeal movements as well as their capacities for complex sensory perceptions, as evidenced by her use of synesthesia to describe how the lizard "listened" with his "eyes." It offers an example of what the early twentieth-century ethologist Jakob von Uexküll termed "Umwelten," perceptual worlds that act like "soap bubble[s]" within which subjects make meaning, whether human or nonhuman (69). Any conceptualization of a holistic, "allencompassing world-space" (70), according to Uexküll, is an anthropocentric "fiction" or "fable." Rather than advocating bland factual descriptions, however, Uexküll stresses how vital it is that humans "imagine" in order to try to understand these nonhuman worlds and the "subjective perceptual signs" that constitute them (70). Mansfield's contention that the lizard "deliberately winked" is obviously fanciful, but if such a statement is anthropomorphic it also shows Mansfield's self-consciousness in regard to her own human alterity from the perspective of the animal. (Is Mansfield winking to Murry, too, we wonder, in acknowledgment of her inventive interpretation?) The descriptions of animals in the above passage also allude to fictional creatures, as signaled by the use of the adjective "slithy": the word's invention has been credited to Lewis Carroll, who popularized it in Through the Looking-Glass.Humpty-Dumpty describes "slithy toves" to Alice in Carroll's novel, explaining that "slithy' means 'lithe and slimy.' 'Lithe' is the same as 'active.' You see it's like a portmanteau-there are two meanings packed up into one word" (187). He continues: "toves' are 'something like badgers—-they're something like lizards—and they're something like corkscrews."' In Mansfield's letter the lizard may not be as fantastical as Carroll's, but her description is 
of a simultaneously material and imaginary environment.

The next paragraph in Mansfield's letter describes how "[t]wo infant wasps came out this morning \& each caught hold of a side of a leaf \& began to tug. It was a brown leaf outside the size of three tea leaves. They became furious-they whimperedwhiney-pined—snatched at each other-wouldn't give way \& finally one rolled over \& couldn't roll back again—just lay there—kicking" (“To J. M. Murry," 27 Sept. 1920, 5354). Once again, attention is paid to the way the insects relate to each other, with anthropomorphic language used to better comprehend the wasps' experience. Yet Mansfield is well aware of the way humans project their own meaning onto animal behavior, with her attempt to do so undermined by the fact that there are no humans in Mansfield's company—only her "invisible play-mate" (54). By playfully signing the letter "Fabretta" (54)—a moniker inspired by the entomologist and pioneer of ethology, JeanHenri Fabre—Mansfield records her position as both observer and creator. If Fabre was among the first to carefully study insect behavior, Mansfield is more attentive to the ways in which such observations are transformed through language. We get a sense, for example, of how restrained Mansfield's anthropomorphism actually is-how carefully she balances human fiction with material fact-if we compare it to the florid manner in which Fabre writes about "the wasp, the irascible bully with a poisoned dagger" in Social Life in the Insect World. ${ }^{16}$

Mansfield's concern with transforming her observations into aesthetic creations is displayed again when she moves to Montana-sur-Sierre in Switzerland, where she is joined by Murry for what would be her last productive, intensive period of writing. On 12 September 1921 she writes to Brett, telling her that she has completed "At the Bay" in a 
letter that also recounts how her cat Wingley "reads Shakespeare with us" (12 Sept. 1921, 279). The letter even strays into bedtime discussions between Mansfield and Murry about what creatures will be included in their future home. "What about bees?" Mansfield asks. Murry responds, "Most certainly bees and I aspire to a goat." Writing to his brother Richard Murry a few days later, Mansfield details how she had been "squirrel-gazing" using field glasses (17 Sept. 1921, 282): "They are exquisite little creatures-so intent, preoccupied, as it were, and so careless. They flop softly from branch to branch, hang upside down, just for the sake of hanging. Some here are as small as rats, with reddish coats and silver bellies. The point about looking at birds and so on through glasses is one sees them in their own world, off their guard. One spies, in fact." The mention of "birds and so on" implies that by this point Mansfield is no novice when it comes to using field glasses, a technological innovation that aided the shift from working with taxonomic specimens to the observation of animal life in dynamic movement. Writing about their role in the late nineteenth and early twentieth centuries, Christina Alt notes that "field-glasses came increasingly into use among naturalists and, by allowing observers to identify species at a distance, rendered obsolete the collector's adage, 'What's hit is history. What's missed is mystery'" (53). ${ }^{17}$ To confirm the impact such observational study of nature has had on her, Mansfield writes a few days later to Brett to tell her that living among the Swiss mountains "has so brought back my love of nature that I shall spend all the rest of my life-trekking" ("To Dorothy Brett," 1 Oct. 1921, 287-88).

Mansfield did spend the remainder of her life, now severely afflicted by the tuberculosis that would kill her in January 1923, engaging with animals in both her 
surroundings and her stories. From Paris on 26 February 1922 she writes to Brett that she has finished "The Fly," which details a "plucky" (479) insect's struggle against a businessman who drowns it in blots of ink, killing and then disposing of it "in the wastepaper basket" (480). Though it perhaps joins "Mr. and Mrs. Dove" in its use of a winged creature in an obviously symbolic way-the fly's battle has been read as symbolizing the "inhuman effects of the First World War" (Alpers, 576-77)—the story also presents the fly's behavior and imagines its experiences: in recovering from its initial fall into the inkpot, the fly "began, like a minute cat, to clean its face" (Mansfield, "The Fly" 479) and rubbed its front legs "joyfully," only to be stunned by the businessman's blot of ink so that "then, as if painfully, it dragged itself forward." In the same letter, Mansfield sketches what would be her last story, "The Canary":

I think my story for you will be about Canaries. The large cage opposite has fascinated me completely. I think \& think about them-their feelings, their dreams, the life they led before they were caught, the difference between the two little pale fluffy ones who were born in captivity \& their grandfather \& grandmother who knew the South American forests and have seen the immense perfumed sea ... Words cannot express the beauty of that high shrill little song rising out of the very stones. It seems one cannot escape Beauty -it is everywhere. ("To Dorothy Brett," 26 Feb. 1922, 76)

The completed story, which details a woman coming to terms with the death of her canary, once again employs a human-animal relationship to explore death and grief. But Mansfield's letter makes it clear that the story originated from an interest in the 
experiences of canaries themselves, as seen in her attention to differences between wild and captive creatures. When we read in the story that the woman's "breast felt hollow, as if it was his [the canary's] cage," we become aware of their close affinity as well as the asymmetry in this domesticated arrangement ("The Canary" 513). There can be little doubt that the canary has penetrated this woman's innermost feelings, even as it is suggested that such feelings had trapped this bird within a distinctly human realm. As such, the story echoes the dual pathos of Mansfield's "Miss Brill," for whom wearing fox fur gives the feeling that "something gentle seemed to move in her bosom" even as the story records a kind of shared pain between the lonely woman and the dead fox (251): "The box that the fur came out of was on the bed. She unclasped the necklet quickly; quickly, without looking, laid it inside. But when she put the lid on she thought she heard something crying" (254).

Once she arrives at Fontainebleau in October 1922 to stay at George Gurdjieff's Institute for the Harmonious Development of Man, Mansfield's fascination with nonhuman environments becomes largely focused on domesticated animals. Not only does she recommend to Murry that he "get some animals" to aid his wellbeing and his work ("To J. M. Murry," 15 Oct. 1922, 298); she also takes great pleasure in "looking after animals" as part of her effort "to try \& learn to live-really live, and in relation to everything—not isolated" (“To S. S. Koteliansky," 19 Oct. 1922, 304). The observation of and caring for animals fosters her desire for a more intimate relationship with them and a greater knowledge of their lives:

I must tell you, darling, my love of cows persists. We now have three. They are real beauties_immense—with short curly hair? fur? wool? 
between their horns. Geese, too, have been added to the establishment. They seem full of intelligence. I am becoming absorbed in animals, not to watch only but to know how to care for them \& to know about them. Why does one live so far away from these things? Bees we shall have later. I am determined to know about bees. ("To J. M. Murry," 19 Nov. 1922, 325)

This passage resonates with a number of Mansfield's earlier reflections. Her wondering why humans "live so far away" from animals echoes her aforementioned concern that "human beings live so remote from all animals." Her emphasis on bovine and anatine "intelligence" marks a shift from her desire to assert such capacities as those that transcend animality in reaction to Lawrence's animal becoming that "denies human life." Most significant, the phrase "becoming absorbed in animals" recalls Mansfield's 1917 letter outlining the "process of becoming the duck." The difference is that in the earlier statement the "duck" was always already figured in linguistic terms: "When I write about ducks" began the passage that would end in Mansfield asserting the way her aesthetic creation exceeds such "objects" to become "more duck, more apple or more Natasha." In contrast, Mansfield's use of the verb "absorbed"- derived from the Middle French absorbir and Latin absorbēre, and meaning to "swallow" or "devour" —implies a consuming of the human by the animal and, therefore, a reversal of the common anthropocentric relationship. The 19 November 1922 letter describes a form of becoming that precedes writing, or, put differently, that creates the very conditions for its possibility. As she notes in one of her last letters to Murry: "I know that one day I shall write a long long story" based on "the most happy feelings listening to the beasts \& looking" (6 Dec. 1922, 331). 
Mansfield's absorption with animals from the time she arrives in Switzerland in May 1921 provides a different perspective on a period often characterized by her "fresh spiritual orientation" in response to the illness taking hold of her body (O'Sullivan and Scott, qtd. in Mansfield, Letters 4 213). Beyond a concern with her own mind, soul, and body, Mansfield's engagement with animal worlds instead reminds us that her final years and months were, as she notes in her journal in October 1922, spent longing to make "close contact [with] what I love-the earth and the wonders thereof, the sea, the sun. All that we mean when we speak of the external world. I want to enter into it, to be part of it, to live in it, to learn from it, to lose all that is superficial and acquired in me and to become a conscious, direct human being" (Notebook 30 287). More than simply indicating her worldview, Mansfield's concern with the entanglement of human and nonhuman life should be understood as deeply affecting her writing and the development of her modernist aesthetics. Mansfield's careful observations of animals and creative encounters with them suggest that literature, rooted in linguistic structures that have traditionally been seen to divide humans from other species, may actually bring us into closer contact with animality and, in the process, we might become more directly human.

\section{Works Cited}

Adams, Carol J. The Sexual Politics of Meat: A Feminist-Vegetarian Critical Theory. 1990. London: Bloomsbury, 2010.

Alpers, Antony. "Commentary." The Stories of Katherine Mansfield. Ed. Alpers. 
Auckland: Oxford UP, 1984. 543-78.

Alt, Christina. Virginia Woolf and the Study of Nature. Cambridge: Cambridge UP, 2010.

Atkinson, Juliette. Introduction. The Mill on the Floss. By George Eliot. Oxford: Oxford UP, 2015. vii-xxviii.

Beer, Gilliam. Darwin's Plots: Evolutionary Narrative in Darwin, George Eliot and Nineteenth-Century Fiction. 1983. Cambridge: Cambridge UP, 2009.

Carroll, Lewis. Alice's Adventures in Wonderland and Through the Looking-Glass. London: Penguin, 2009.

Chekhov, Anton. "Happiness."Trans. Constance Garnett. 201 Stories by Anton Chekhov. Eldritch Press, 26 Aug. 1999. Web. 20 Feb. 2017.

Corbett, Mary Jean. "The Crossing o' Breeds' in The Mill on the Floss." Victorian Animal Dreams: Representations of Animals in Victorian Literature and Culture. Ed. Deborah Denenholz Morse and Martin A. Danahay. Aldershot: Ashgate, 2007. $121-44$

Deleuze, Gilles, and Félix Guattari. A Thousand Plateaus. 1980. Trans. Brian Massumi. London: Continuum, 2004.

De Rijke, Victoria. Duck. London: Reaktion, 2008.

Dilworth, Thomas. "Monkey Business: Darwin, Displacement, and Literary Form in Katherine Mansfield's 'Bliss.”' Studies in Short Fiction 35.2 (1998): 141-52.

Eliot, George. The Mill on the Floss. 1860. Oxford: Oxford UP, 2015.

Fabre, J. H. Social Life in the Insect World. 1912. Trans. Bernard Miall. London: T. Fisher Unwin, 1922. Project Gutenberg. Web. 12 Aug. 2016.

Harvey, Melinda. "Katherine Mansfield's Menagerie." Katherine Mansfield and Literary 
Modernism. Ed. Janet Wilson, Gerri Kimber, and Susan Reid. London: Continuum, 2011. 202-10.

Ibsen, Henrik. The Wild Duck. Trans. James McFarlane. An Enemy of the People, The Wild Duck, Rosmersholm. Ed. McFarlane. Oxford: Oxford UP, 2009. 107-220. Jones, Kathleen. Katherine Mansfield: The Story-Teller. Edinburgh: Edinburgh UP, 2010.

Kaplan, Sydney Janet. Circulating Genius: John Middleton Murry, Katherine Mansfield and D. H. Lawrence. Edinburgh: Edinburgh UP, 2010.Kimber, Gerri, and Angela Smith. "Reviews: Introduction." Mansfield, Poetry and Critical Writings 425-28.

Kobler, J. F. Katherine Mansfield: A Study of the Short Fiction. Boston: Twayne, 1990. Lallier, Andrew. "The Generations of Ants and Beavers': Classical Economics and Animals in The Mill on the Floss." George Eliot Review 43 (2012): 47-55.

Mansfield, Katherine. "The Advanced Lady." 1911. Mansfield, Collected Fiction 1895$1915,234-42$.

—. "At the Bay." 1921. Mansfield, Collected Fiction 1916-1922, 342-72.

—. "The Canary." 1922. Mansfield, Collected Fiction 1916-1922, 511-15.

-. The Collected Fiction of Katherine Mansfield, 1898-1915. Vol. 1 of The Edinburgh Edition of the Collected Works of Katherine Mansfield. Edinburgh: Edinburgh UP, 2012.

—. The Collected Fiction of Katherine Mansfield, 1916-1922. Ed. Gerri Kimber and Vincent O'Sullivan. Vol. 2 of The Edinburgh Edition of the Collected Works of Katherine Mansfield. Edinburgh: Edinburgh UP, 2012.

-. The Collected Letters of Katherine Mansfield. Ed. Vincent O'Sullivan and Margaret 
Scott. 5 vols. Oxford: Oxford UP, 1984-2008.

—. "Die Einsame (The Lonely One)." 1904. Mansfield, Collected Fiction 1895-1915, 2022.

—. "The Fly." 1922. Mansfield, Collected Fiction 1916-1922, 476-80.

—. "Juliet." 1906. Mansfield, Collected Fiction 1895-1915, 37-61.

—. The Katherine Mansfield Notebooks: Complete Edition. Ed. Margaret Scott. Minneapolis: U of Minnesota P, 2002.

—. "The Lost Girl." Mansfield, Poetry and Critical Writings 706-08.

—. "Miss Brill." 1920. Mansfield, Collected Fiction 1916-1922, 250-55.

—. "Moods, Songs and Doggerels." Mansfield, Poetry and Critical Writings 429-30.

-. Notebook 12. Mansfield, Notebooks, vol. 2, 133-44.

-. Notebook 42. Mansfield, Notebooks, vol. 2, 158-64.

-. Newberry Notebook 7. Mansfield, Notebooks, vol. 2, 278-82.

-. Notebook 30. Mansfield, Notebooks, vol. 2, 285-89.

—. "The Pine Trees, the Sparrows, and You and I." 1903. Mansfield, Collected Fiction 1895-1915, 10-12.

-. The Poetry and Critical Writings of Katherine Mansfield. Ed. Gerri Kimber and Angela Smith. Vol. 3 of The Edinburgh Edition of the Collected Works of Katherine Mansfield. Edinburgh: Edinburgh UP, 2014.

—. "Prelude." 1917. Mansfield, Collected Fiction 1916-1922, 56-93.

-. "A Ship Comes into the Harbour." Mansfield, Poetry and Critical Writings 532-35.

—. "A Short Story." Mansfield, Poetry and Critical Writings 473-75.

—. "Something Childish But Very Natural." 1914. Mansfield, Collected Fiction 1895- 
1915, 2012. 373-88.

—. "To Beatrice Campbell." 4 May 1916. Mansfield, Letters 1, 260-62.

—. "To Dorothy Brett." 11 Oct. 1917. Mansfield, Letters 1, 330-31.

—. "To Dorothy Brett." 29 July 1921. Mansfield, Letters 4, 256-58.

—. "To Dorothy Brett." 4 Aug. 1921. Mansfield, Letters 4, 259-61.

—. "To Dorothy Brett." 12 Sept. 1921. Mansfield, Letters 4, 277-80.

—. "To Dorothy Brett." 1 Oct. 1921. Mansfield, Letters 4, 286-89.

—. "To Dorothy Brett." 15 Oct. 1921. Mansfield, Letters 4, 295-97.

—. "To Dorothy Brett." 26 Feb. 1922. Mansfield, Letters 5, 74-77.

—. "To J. M. Murry." 23 Oct. 1919. Mansfield, Letters 3, 44-46.

—. "To J. M. Murry." 25 Nov. 1919. Mansfield, Letters 3, 117-20.

—. "To J. M. Murry." 19 and 21 Sept. 1920. Mansfield, Letters 4, 43-45.

—. "To J. M. Murry." 27 Sept. 1920. Mansfield, Letters 4, 52-54.

—. "To J. M. Murry." 15 Oct. 1922. Mansfield, Letters 5, 298-99.

—. "To J. M. Murry." 19 Nov. 1922. Mansfield, Letters 5, 324-25.

—. "To J. M. Murry." 6 Dec. 1922. Mansfield, Letters 5, 330-31.

—. "To Ottoline Morrell." Early May 1919. Mansfield, Letters 2, 317.

—. "To Ottoline Morrell." 27 June 1919. Mansfield, Letters 2, 333-35.

—. "To Ottoline Morrell." 24 July 1921. Mansfield, Letters 4, 251-53.

—. "To Richard Murry." 17 Sept. 1921. Mansfield, Letters 4, 282.

—. "To S. S. Koteliansky." 7 Apr. 1919. Mansfield, Letters 2, 309.

—. "To S. S. Koteliansky." 19 Oct. 1922. Mansfield, Letters 5, 303-04.

Matthews, Peter. "Myth and Unity in Mansfield's 'At the Bay."' Journal of New Zealand 
Literature 23.2 (2005): 47-61.

McHugh, Susan. Animal Stories: Narrating Across Species Lines. Minneapolis: $U$ of Minnesota P, 2011.

Perkins, David. Romanticism and Animal Rights. Cambridge: Cambridge UP, 2003.

Smith, Angela. Katherine Mansfield: A Literary Life. Basingstoke: Palgrave, 2000.

—. Katherine Mansfield and Virginia Woolf: A Public of Two. Oxford: Clarendon, 1999.

Ryan, Derek. "Entangled in Nature: Deleuze's Modernism, Woolf's Philosophy, and Spinoza's Ethology." Understanding Deleuze, Understanding Modernism. Ed.

Paul Ardoin, S. E. Gontarski, and Laci Mattison. New York: Bloomsbury, 2014. $151-68$.

Uexküll, Jakob von. A Foray into the Worlds of Animals and Humans. Trans. Joseph D. O'Neil. A Foray into the Worlds of Animals and Humans, with A Theory of Meaning. Minneapolis: U of Minnesota P, 2010. 41-138.

Waterlow, Sydney. "George Eliot, 1819-1880." Athenaeum 4673 (21 Nov. 1919): 121719.

\section{Notes}


${ }^{1}$ In her introduction to Eliot's novel, Atkinson notes "the frequency with which its characters are compared to animals" (xxii). Examples include "affinities [that] are subtle" (xxiii): we read of ducks "dipping their heads far into water" (Eliot 8), which anticipates Maggie "dipp[ing] her head in a basin of water" (26) before being described as a "little duck" by Tom (38). This affectionate comparison is starkly contrasted by Mansfield in her rendering of Kezia's trauma at the beheading of the duck in "Prelude," discussed in this essay.

${ }^{2}$ See Corbett for a discussion of the Darwinian dimensions of Eliot's exploration of gender and animality. Eliot's engagement with Darwin is more widely explored in Gillian Beer's classic study, Darwin's Plots.

${ }^{3}$ For several examples see Lallier, who argues that "Eliot's attention to working animals such as horses and dogs, and her interest in their subjective interiorities" challenges "the tendency in political economy to reduce animals to commodities" (49). ${ }^{4}$ In Katherine Mansfield: A Literary Life, Smith explains that Mansfield's letter to Brett shows "how close she still is to a Fauvist aesthetic" (112). The term fauvism has its own strong creaturely connotations, deriving from the French fauve, meaning "wild animal." ${ }^{5}$ Matthews is influenced by the notion of "becoming" articulated by Deleuze and Guattari. His essay opens with an epigraph from $A$ Thousand Plateaus that proposes cross-species entanglements that are based on "alliance" and "transversal communications" (263) rather than "resemblance" (262), "imitation," or "identification." However, Matthews overlooks an allusion Deleuze and Guattari make, via a review by Virginia Woolf, to a passage from Mansfield's notebook where she details "the poor underfed dog" who is "the spirit of the street" (Notebook 12138). Read through both Woolf and Deleuze and Guattari, Mansfield's notebook entry can be understood as presenting an "ethological assemblage" that brings "human and nonhuman into an immanent arrangement" (Ryan, "Entangled in Nature" 160).

${ }^{6}$ Smith also contrasts Mansfield's reading of Woolf and Lawrence, though her primary aim is to distinguish Mansfield's Fauvist aesthetic: "she feels that his [Lawrence's] animality is not that of the Fauvist but of instinct without intuition and imagination" whereas she felt "Virginia Woolf was not sufficiently physical" (Katherine Mansfield: $A$ Literary Life 111-12). 
7 See also Mansfield's review of "Kew Gardens" in the Athenaeum, which describes it as "leisure[ly]" ("A Short Story" 474), "poise[d]," and "indifferent" (475), a far cry from Lawrence's visceral animality. Mansfield may have sparked the idea for "Kew Gardens" in a letter to Woolf, now lost, "suggesting a story about a garden" (Kimber and Smith, 475).

${ }^{8}$ McHugh describes "narrative ethology" as "the ongoing and systematic analysis of how forms of species remain embedded in storytelling processes" (5) through a critical reading "that emphasizes embodied relations of agency and form as distinct from, say, the content through which ethological, fictional, and all other narratives get sorted and shelved as the political problems of representation" (218).

${ }^{9}$ Sentimentality was one of the features Mansfield appeared to dislike in the animal writing of her literary antecedents, as evidenced in her review of John Galsworthy's Moods, Songs and Doggerels (1912). Quoting from "To My Dog," in which the speaker professes that "through the ages we'll retrieve / Each other's scent and company," she cuttingly remarks: "Mr Galsworthy is wise in that he avoids all mention of the word 'poetry' in connection with his verses" ("Moods, Songs and Doggerels" 429-30). ${ }^{10}$ Mansfield's fondness for Romantic poetry is well known, with critics such as Kobler even asserting that "Mansfield was a Wordsworthian romantic artist" (121). While some of her early writings might support Kobler's claim-and it is clear she was influenced by her reading of the Romantics - to categorize Mansfield's approach to nature in this way, as this essay shows, is at odds with the development of her modernist aesthetics.

${ }^{11}$ Kaplan draws out the differences in the gendered dimension between this scene and Murry's masculine, "ejaculatory" dream sequences in The Things We Are (151). 12 Despite its feminine signification, "duck" has long been associated with masculinity and war, which can be seen in the many duck metaphors that "originate in military terms" (De Rijke 100). De Rijke explains, for example, that in the First World War "Duck cloth is the hardwearing cotton canvas that sea bags and boat covers were made of. Duckboard is military planking, as found in the trenches; a duckboard harrier was a messenger; a duckboard glide an after-dark movement along a trench" (99-100). ${ }^{13}$ Elsewhere Mansfield's stories display a creative fascination with notions of "savage origins," as she puts it in "The Advanced Lady" (238). Dilworth shows how monkey 
figures are used in "Bliss" to satirize "aesthetically cultivated, pretentious sophisticates" even as they mark "the momentous imaginative change brought about" by Darwin's theory of evolution (144).

${ }^{14}$ By contrast, the only mention of sheep in "Prelude" takes place within an economy of classification and a human-centered perspective: "What is the difference between a ram and a sheep?" Kezia asks. The answer: "Well, a ram has horns and runs for you" (61). ${ }^{15}$ Mansfield's focus on Florrie's thoughts and feelings may have been influenced by the birth of the arrival of two kittens, Wingley and Athenaeum, in 1919. At the same time that she started work on "At the Bay" she was recording notes on the kittens' behavior in her notebooks. For example, she describes Athenaeum's "faint whispering" and "tiny footprints" (158) and Wingley's reaction to the rain: "delicately, lifting his paws, pointing his ears, very afraid that a big wave will overtake him, he wades over the lake of green grass" (Notebook 42 159).

${ }^{16}$ Fabre goes on to describe how "the little grey lizard and the ant" are "the first to come to the living feast and the most eager at the slaughter" of crickets he is breeding in his garden. Mansfield's 27 September 1920 letter to Murry follows a similar pattern by introducing lizard, ant, and then wasp.

17 As Alt notes, Woolf's "new naturalist" character Ralph Denham uses field-glasses in Night and Day (155). Given that Mansfield read and reviewed the novel (see "A Ship"), it is possible Woolf's description of field glasses left a lasting impression on her. 